\title{
Enhancing the anti-angiogenic action of histone deacetylase inhibitors
}

\author{
Selena Kuljaca1, Tao Liu ${ }^{1}$, Andrew EL Tee ${ }^{1}$, Michelle Haber ${ }^{1}$, \\ Murray D Norris ${ }^{1}$, Tanya Dwarte ${ }^{1}$ and Glenn M Marshall*1,2
}

\begin{abstract}
Address: 'The Children's Cancer Institute Australia for Medical Research, The University of New South Wales, Sydney, NSW 2031, Australia and 2The Centre for Children's Cancer and Blood Disorders, Sydney Children's Hospital, Randwick, Sydney, NSW 2031, Australia

Email: Selena Kuljaca - skuljaca@ccia.unsw.edu.au; Tao Liu - tliu@ccia.unsw.edu.au; Andrew EL Tee - atee@ccia.unsw.edu.au; Michelle Haber - mhaber@ccia.unsw.edu.au; Murray D Norris - mnorris@ccia.unsw.edu.au; Tanya Dwarte - dwarte@ccia.unsw.edu.au; Glenn M Marshall* - g.marshall@unsw.edu.au

* Corresponding author
\end{abstract}

Published: 25 October 2007

Molecular Cancer 2007, 6:68 doi:10.1 186/1476-4598-6-68
Received: 25 July 2007

Accepted: 25 October 2007

This article is available from: http://www.molecular-cancer.com/content/6/1/68

(c) 2007 Kuljaca et al; licensee BioMed Central Ltd.

This is an Open Access article distributed under the terms of the Creative Commons Attribution License (http://creativecommons.org/licenses/by/2.0), which permits unrestricted use, distribution, and reproduction in any medium, provided the original work is properly cited.

\begin{abstract}
Background: Histone deacetylase inhibitors (HDACls) have many effects on cancer cells, such as growth inhibition, induction of cell death, differentiation, and anti-angiogenesis, all with a wide therapeutic index. However, clinical trials demonstrate that HDACls are more likely to be effective when used in combination with other anticancer agents. Moreover, the molecular basis for the anticancer action of HDACls is still unknown. In this study, we compared different combinations of $\mathrm{HDACls}$ and anti-cancer agents with anti-angiogenic effects, and analysed their mechanism of action.

Results: Trichostatin A (TSA) and $\alpha$-interferon (IFN $\alpha$ ) were the most effective combination across a range of different cancer cell lines, while normal non-malignant cells did not respond in the same manner to the combination therapy. There was a close correlation between absence of basal P2 I WAFI expression and response to TSA and IFN $\alpha$ treatment. Moreover, inhibition of p2 IWAFI expression in a P2IWAFI-expressing breast cancer cell line by a specific siRNA increased the cytotoxic effects of TSA and IFN $\alpha$. In vitro assays of endothelial cell function showed that TSA and IFN $\alpha$ decreased endothelial cell migration, invasion, and capillary tubule formation, without affecting endothelial cell viability. TSA and IFN $\alpha$ co-operatively inhibited gene expression of some pro-angiogenic factors: vascular endothelial growth factor, hypoxia-inducible factor I $\alpha$ and matrix metalloproteinase 9, in neuroblastoma cells under hypoxic conditions. Combination TSA and IFN $\alpha$ therapy markedly reduced tumour angiogenesis in neuroblastoma-bearing transgenic mice.
\end{abstract}

Conclusion: Our results indicate that combination TSA and IFN $\alpha$ therapy has potent cooperative cytotoxic and anti-angiogenic activity. High basal p2 I WAFI expression appears to be acting as a resistance factor to the combination therapy.

\section{Background}

Acetylation and deacetylation of histones by histone acetyltransferases and histone deacetylases (HDACs) alter chromatin structure and modulate transcriptional regulation (reviewed in [1-3]. Inhibitors of HDACs (HDACIs) are emerging as a new class of anticancer agents. HDACIs 
induce cancer cell differentiation, growth arrest, programmed cell death, and inhibit tumour-driven angiogenesis $[1,3]$. Clinical trials with HDACIs in cancer patients demonstrate that HDACI treatment leads to tumour regression and symptomatic improvement in some heavily pre-treated and multiply relapsed patients, with a surprisingly low side-effect profile [1,4]. However, a large proportion of the patients are not sensitive to the treatment, demonstrating the need to examine the effectiveness of HDACIs in combination with other anti-cancer agents.

Angiogenesis is vital for tumor progression and metastasis $[5,6]$. As anti-angiogenic therapy is generally less toxic and better tolerated than conventional cytotoxic chemotherapy, strategies which combine anti-angiogenic agents with other anti-cancer drugs have been the focus of current clinical trials to widen the therapeutic index. The interferons (IFNs) are a family of naturally occurring cytokines with anti-proliferative and anti-angiogenic effects $[7,8]$. Through inhibiting pro-angiogenic gene expression and acting directly on endothelial cells, $\alpha$-interferon (IFN $\alpha$ ) suppresses angiogenesis and tumour growth in vitro and in vivo $[7,9]$. Rapamycin and its derivatives also inhibit tumour cell proliferation and angiogenesis by acting on the mammalian target of rapamycin and suppressing the transcriptional activity of pro-angiogenic hypoxia-inducible factor $1 \alpha(H I F 1 \alpha)$, (reviewed in [10]). While clinical trials with IFN $\alpha$, rapamycin and its derivatives used as single agents have shown some effects, none of the drugs are effective alone in the majority of patients.

It has been reported that a combination therapy with the HDACI, valproate (VPA), and IFN $\alpha$ exerts synergistic anticancer effects in neuroblastoma BE(2)-C cells both in vitro and in vivo $[11,12]$. Here we evaluated the anticancer actions of combination therapy with HDACIs (Trichostatin A [TSA] or VPA) and anti-cancer agents with anti-angiogenic function (IFN $\alpha$, rapamycin), and, sought to determine their mechanism of action.

\section{Results \\ TSA and IFN $\alpha$ exerted co-operative cytotoxic effects in cancer cell lines from a range of different tissue origins}

The combination of the HDACI, VPA, and IFN $\alpha$ demonstrated synergistic combinational anti-cancer effects in neuroblastoma $\mathrm{BE}(2)-\mathrm{C}$ cells both in vitro and in vivo $[11,12]$. We investigated the synergistic anti-cancer effect of IFN $\alpha$ combined with other HDACIs, and, in cancer cell lines of other tissue origins. We treated breast, lung, colon and prostate cancer cells and MRC- 5 normal non-malignant fibroblasts with control, $0.02 \mu \mathrm{M}$ TSA and/or 500 $\mathrm{IU} / \mathrm{ml} \mathrm{IFN} \alpha$, and, then assessed for cell viability. As shown in Figure 1A, all of the cancer cell lines tested were sensitive to the cytotoxic effects of the combination, and there was a significant cooperative effect of TSA and IFN $\alpha$ in eight of the nine cell lines tested, with MDA-MB-468 as the only exception. MCF-7, Calu-6, H460, LNCaP, DU145, HT-29, Caco-2 and BE(2)-C cells were all sensitive to TSA, generally less sensitive to IFN $\alpha$, and significantly more sensitive to TSA and IFN $\alpha$ combined. MDA-MB-468 breast cancer cells were sensitive to IFNa but resistant to TSA, and no more sensitive to the combination than IFN $\alpha$ alone. When cell sensitivity to the combination treatment was calculated as a percentage of TSA alone (or IFN $\alpha$ alone in case of MDA-MB-468), BE(2)-C, HT-29 and Calu-6 were found to be the most sensitive (Figure 1A). Importantly, the normal non-malignant MRC-5 fibroblasts were resistant to the treatment of TSA alone, IFN $\alpha$ alone and TSA plus IFN $\alpha$ combination therapy (Figure 1B). Immunoblot analysis of acetylated histone $\mathrm{H} 3$ revealed that treatment with TSA alone or TSA plus IFN $\alpha$ for 6 hours induced drastic histone acetylation in the MRC-5 cells (Figure 1B).

\section{SAHA and IFN $\alpha$ exerted co-operative cytotoxic effects in cancer cell lines, but not in normal cells}

The HDACI, SAHA (vorinostat), is in clinical use for the treatment of cutaneous T-cell lymphoma. We, therefore, tested whether a combination of SAHA and INF $\alpha$ exerted co-operative anti-cancer effects. Neuroblastoma BE(2)-C, breast cancer MCF-7, and normal lung fibroblast MRC-5 cells were treated with control, $0.5 \mu \mathrm{M}$ SAHA, $500 \mathrm{IU} / \mathrm{ml}$ INF $\alpha$ or SAHA plus INFa for 3 days. Alamar blue assays revealed that SAHA and INF $\alpha$ co-operatively reduced the viability of $\mathrm{BE}(2)-\mathrm{C}$ and MCF-7 cells, although the magnitude was smaller than TSA and INFa. A combination of SAHA and INF $\alpha$ did not co-operatively reduce the viability of MRC-5 cells (Figure 2).

\section{The effects of other HDACls and anti-cancer agents used in combination}

We compared the cytotoxicity of the TSA and IFN $\alpha$ combination (Figure 1A) with combinations of another HDACI VPA and IFN $\alpha$ (Figure 3A). The effect of VPA and IFN $\alpha$ combination therapy on cell viability was similar to TSA and IFN $\alpha$ for the BE(2)-C neuroblastoma cells. However, TSA and IFN $\alpha$ were more effective in MCF-7 and Calu- 6 cells than VPA and IFN $\alpha$. Similar to TSA and IFN $\alpha$, VPA and IFN $\alpha$ did not show any co-operative cytotoxic effects on normal MRC-5 fibroblasts (Figure 3C). We next compared the cytoxicity of the TSA and IFNa combination (Figure 1A), the VPA and IFNa combination (Figure 3A) with VPA combined with another emerging anticancer agent with both cytotoxic and anti-angiogenic actions, rapamycin [10] in BE(2)-C and MCF-7 cells (Figure 3B). The VPA and rapamycin treatment had significant cytotoxic effects compared with VPA alone, but the magnitude of these effects was much smaller than VPA and IFN $\alpha$ or TSA and IFN $\alpha$. 

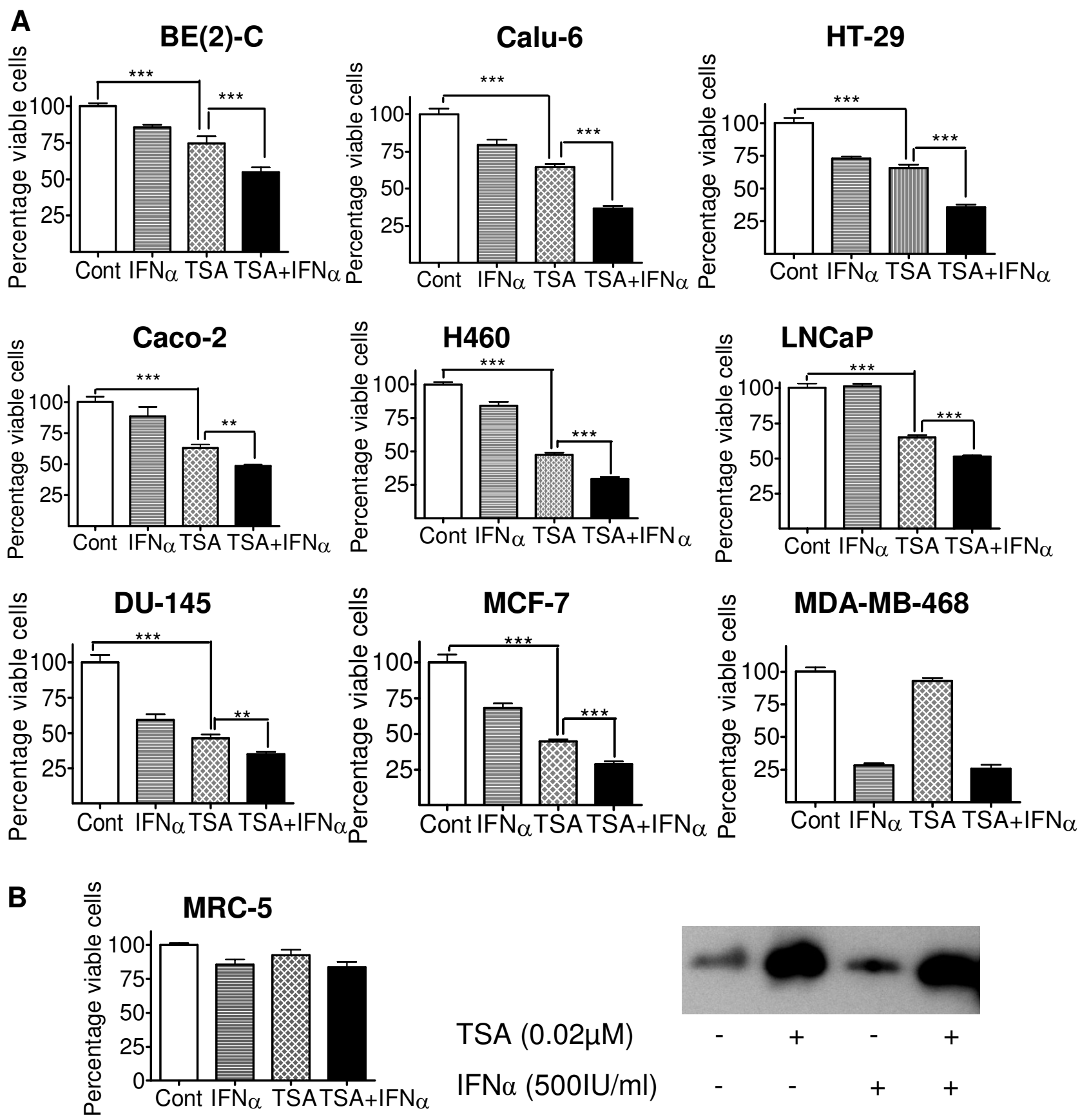

TSA $(0.02 \mu \mathrm{M})$

IFN $\alpha(500 \mathrm{IU} / \mathrm{ml})$
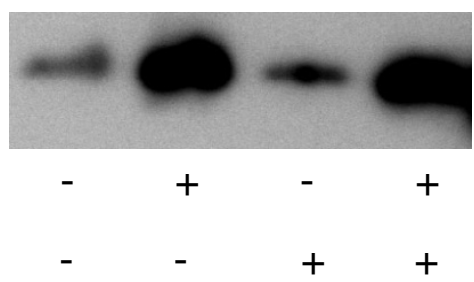

\section{Figure I}

TSA and IFN $\alpha$ exerted co-operative cytotoxic effects in cancer cell lines from a range of different tissue origins, but not in normal non-malignant cells. A. Neuroblastoma [BE(2)-C], breast (MCF-7 and MDA-MB-468), lung (H460 and Calu-6), prostate (DU- 45 and LNCaP), and colon (HT-29 and Caco-2) cancer cells were treated with control (Cont), $0.02 \mu M$ TSA and/or 500 $\mathrm{IU} / \mathrm{ml}$ IFN $\alpha$ for 72 hours. Cell viability was examined using the Alamar blue assay, measured as optical density (OD) units of absorbance, and expressed as the absorbance of treated over control samples (ie., \% viable cells). $* * p<0.01$, $* * * p<0.00 \mathrm{I}$. B. MRC- 5 cells were treated with control, $0.02 \mu \mathrm{M}$ TSA and/or $500 \mathrm{IU} / \mathrm{ml}$ IFN $\alpha$ for 72 hours, and cell viability was assessed as above. Moreover, histone protein was extracted and subject to immunoblot analysis with anti-acetylated histone $\mathrm{H} 3$ antibody, after 6 hour exposure to control, TSA and/or IFN $\alpha$. 

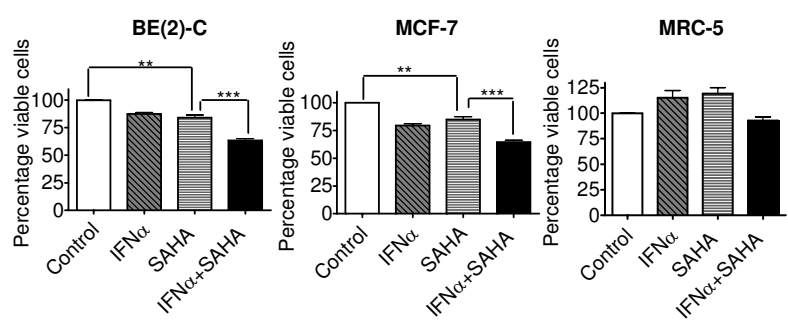

\section{Figure 2}

SAHA and IFN $\alpha$ exerted co-operative cytotoxic effects in cancer cell lines, but not in normal non-malignant cells. Neuroblastoma $\mathrm{BE}(2)-\mathrm{C}$, breast cancer MCF-7, and normal nonmalignant lung MRC-5 fibroblasts were treated with control, $0.5 \mu \mathrm{M}$ SAHA and/or $500 \mathrm{IU} / \mathrm{ml}$ IFN $\alpha$ for 72 hours. Cell viability was examined using the Alamar blue assay, measured as optical density (OD) units of absorbance, and expressed as the absorbance of treated over control samples (ie., \% viable cells). $* \mathrm{p}<0.05$, ** $\mathrm{p}<0.01$, *** $\mathrm{p}<0.001$.

\section{Absence of P2 I WAFI expression correlated with sensitivity to TSA and IFN $\alpha$ combination therapy}

Up-regulation of p21 WAF1 expression, and p21 WAF1 induced cell cycle arrest, have been regarded as one of the main mechanisms through which HDACIs exert their anti-cancer effects[13]. We examined the role of p21WAF1 in cancer cell sensitivity to the combination therapy. Immunoblot analysis of p $21^{\mathrm{WAF} 1}$ expression was carried out with protein extracted from the eight cell lines of breast, lung, prostate and colon origins (Figure 4A). p21WAF1 was basally expressed in untreated H460, DU145, LNCaP, MCF-7 and MDA-MB-468 cells, but not expressed in Calu-6, HT-29 and Caco-2 cells. Compared with control, TSA induced p21 WAF1 expression in H460, MCF-7 and LNCaP cells. IFN $\alpha$ up-regulated p21 2 WAF1 only in DU-145 cells, and, combination therapy increased $\mathrm{p} 21^{\mathrm{WAF} 1}$ in all four cell lines. p21 WAF1 protein was expressed but not altered by treatment with TSA and/or IFN $\alpha$ in MDA-MB-468 cells. Thus, the cancer cell lines which did not have basal expression of p21 ${ }^{\text {WAF1 }}$ were generally more sensitive to the combination therapy than those cancer cells expressing p21 WAF1. This correlation suggested expression of $\mathrm{p} 21^{\mathrm{WAF} 1}$ might render cancer cells insensitive to the combination therapy.

To determine the role of $\mathrm{p} 21^{\mathrm{WAF} 1}$ expression in cancer cell sensitivity to TSA and IFN $\alpha$ combination therapy, MCF-7 cells were transfected with control, scrambled siRNA or siRNA specifically targeting p $21^{\mathrm{WAF} 1}$, and, then treated with control, TSA and/or IFN $\alpha$. RT-PCR and immunoblot analysis revealed that $\mathrm{p} 21^{\mathrm{WAF} 1} \mathrm{mRNA}$ and protein were knocked down by approximately $75 \%$ by the p 21 WAF1 siRNA, compared with scrambled control (Figure 4B). The p21 WAF1 siRNA significantly increased the sensitivity of
MCF-7 cells to TSA and IFN $\alpha$ alone, and, in combination, as measured by cell viability assays ( $\mathrm{p}<0.01)$ (Figure $4 \mathrm{C})$.

\section{HDACI and IFN $\alpha$ co-operatively inhibit endothelial cell functions and pro-angiogenic gene expression in cancer cells in vitro}

Since HDACIs [2,14] and IFN $\alpha[8,9]$ are known to suppress angiogenesis and tumour growth by acting directly on endothelial cells, we further investigated whether the combination of TSA and IFN $\alpha$ could inhibit endothelial cell function. To exclude the possibility that co-operative anti-angiogenic effects by TSA and IFN $\alpha$ were due to cytotoxicity, we first determined the optimal dosages of TSA and IFN $\alpha$ with Alamar blue cell viability assays. After treatment for 18 hours under normoxic or hypoxic conditions $\left(1 \% \mathrm{O}_{2}\right)$, a combination of $0.1 \mu \mathrm{M}$ TSA and $500 \mathrm{IU} /$ $\mathrm{ml}$ IFN $\alpha$ was found to have no cytotoxicity on endothelial cells within 18 hours after treatment (Figure 5A). These doses were, therefore, used in all endothelial cell function studies. Surprisingly, TSA or IFN $\alpha$ alone stimulated endothelial cell migration toward the chemoattractant, vascular endothelial growth factor (VEGF) (Figure 5B). In contrast, the combination of TSA and IFN $\alpha$ suppressed endothelial cell migration under both hypoxic (Figure 5B) or normoxic conditions (data not shown). Compared with control, IFN $\alpha$ or TSA alone reduced endothelial cell invasion through Matrigel by 35\% and 60\%, respectively, whereas the combination of TSA and IFN $\alpha$ decreased cell invasion by $80 \%$, under normoxic (data not shown) or hypoxic conditions (Figure 5C). Under normoxic conditions, compared with control, IFN $\alpha$ or TSA alone decreased the number of complete branches per branching point by $30 \%$ and 50\%, respectively, while TSA and IFN $\alpha$ did not further decrease complete branches per branching point (data not shown). In contrast, under hypoxic conditions, the combination of TSA and IFN $\alpha$ decreased complete branches per branching point by $50 \%$, while TSA or IFN $\alpha$ alone reduced the average numbers of complete branches from a branching point by only 25\% (Figure 5D).

We next evaluated whether the combination of TSA $[15,16]$ and IFN $\alpha[7,17]$ represses pro-angiogenic gene expression, as measured by RT-PCR, in neuroblastoma $\mathrm{BE}(2)-\mathrm{C}$ cells. Compared with treatment with TSA or IFN $\alpha$ alone, the combination therapy significantly down-regulated gene expression of HIF1 $\alpha$, VEGF and MMP-9 under normoxic conditions at 72 hours after treatment, while no co-operative effects were observed on the expression of MMP-2, activin A, thrombospondin-1, von HippelLindau protein and bFGF (data not shown). Suppression of HIF1 $\alpha$, VEGF and MMP-9 gene expression by TSA and IFN $\alpha$ was more significant, when compared with TSA or IFN $\alpha$ alone, under hypoxic conditions (Figure 5E). In the case of HIF1 $\alpha$ and VEGF, IFN $\alpha$ alone repressed gene 
A
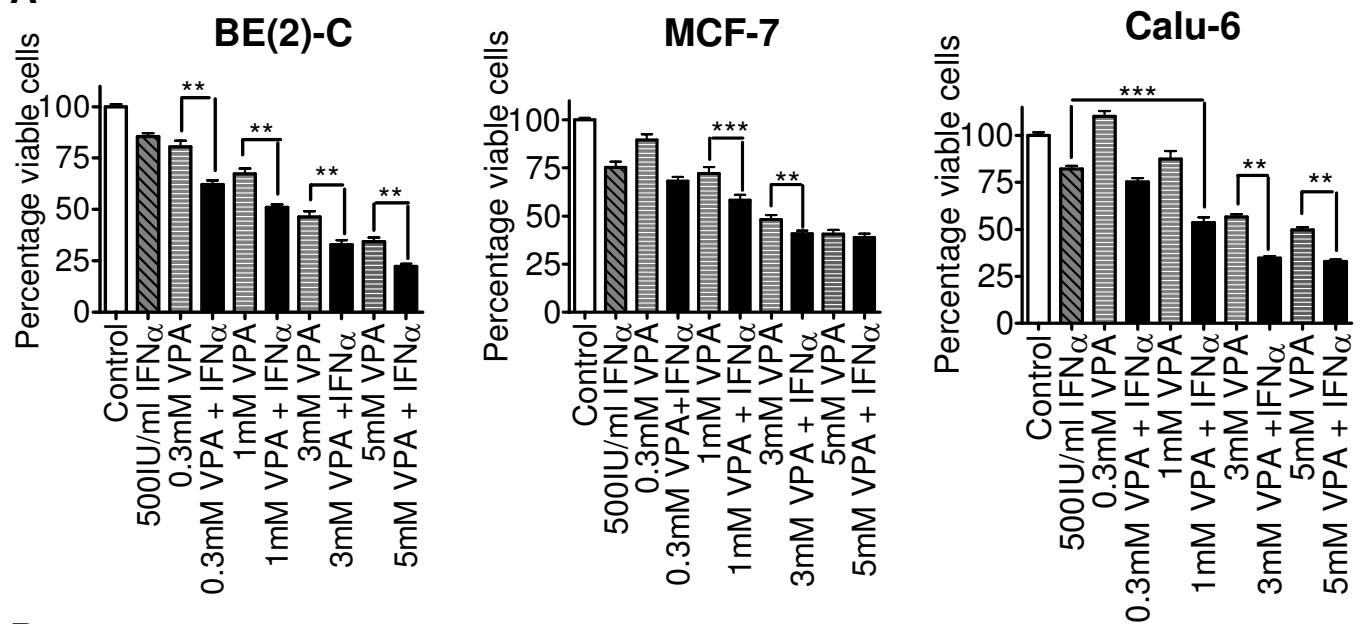

B
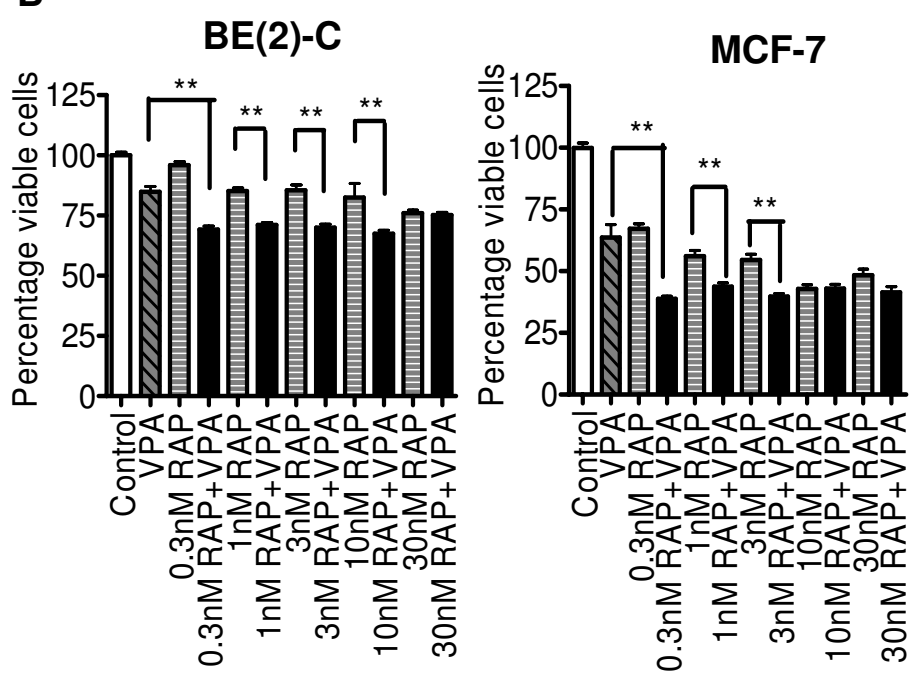

C

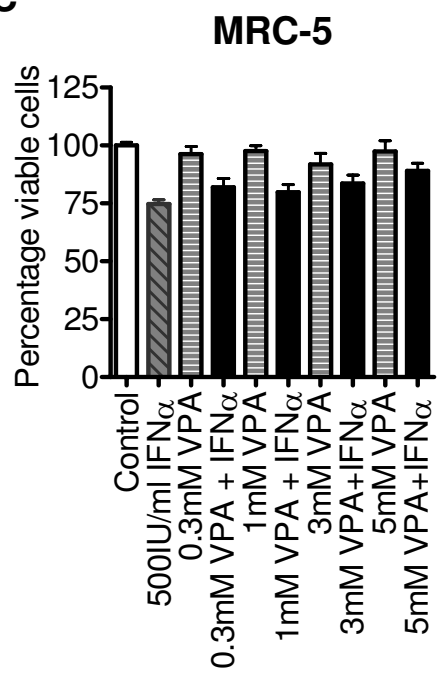

\section{Figure 3}

The cytotoxic effects of other HDACl combination therapies. A. Neuroblastoma [BE(2)-C], breast (MCF-7), and lung (Calu-6) cancer cell lines were treated with either control, $500 \mathrm{IU} / \mathrm{ml}$ IFN $\alpha$ and/or various dosages of VPA for 72 hours B. In separate experiments, BE(2)-C and MCF-7 cells were treated with control, I mM VPA and/or various dosages of rapamycin (RAP) for 72 hours. C. Non-malignant lung fibroblast (MRC-5) cells were treated with a range of VPA doses alone, or in combination with $500 \mathrm{IU} / \mathrm{ml}$ IFN $\alpha$. Cell viability was examined by the Alamar blue assay, measured as optical density (OD) units of absorbance, and expressed as a percentage of absorbance for treated samples, over that for control samples (ie., \% viable cells). ${ }^{* *} \mathrm{P}$ $<0.01$, *** $\mathrm{p}<0.001$.

expression, however, the combination still had a more significant repressive effect, compared with IFN $\alpha$ alone (p $<0.05$ ). Although MMP-9 gene expression was stimulated by IFN $\alpha$ and TSA alone, the combination suppressed its expression, when compared with control-treated samples $(\mathrm{p}<0.05)$.
TSA and IFN $\alpha$ co-operatively suppress tumour-driven angiogenesis in neuroblastoma-bearingN-Myc transgenic mice

Lastly, we tested whether the combination of TSA and IFN $\alpha$ could co-operatively inhibit tumor-driven angiogenesis in vivo. Abdominal neuroblastoma first became palpable in $100 \%$ of homozygote N-Myc transgenic mice at 4 weeks of age [18]. Cohorts of five homozygous MYCN 


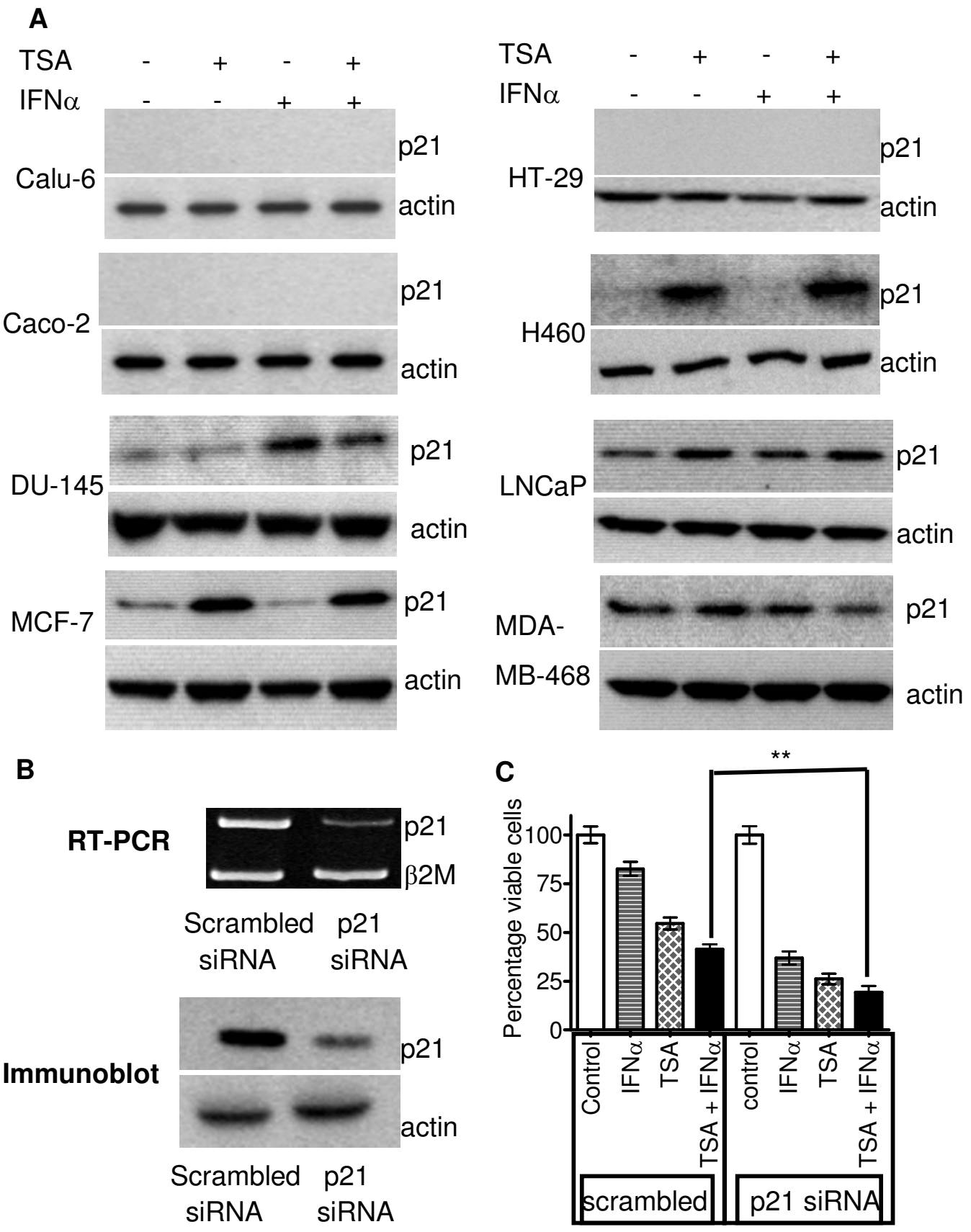

Figure 4

Absence of p2IWAFI expression correlated with sensitivity to TSA and IFN $\alpha$ combination therapy. A. MCF-7, MDA-MB-468, H460, Calu-6, DU- I45, LNCaP, HT-29 and Caco-2 cells were treated with control, $0.02 \mu M$ TSA, 500 IU/ml IFN $\alpha$, or TSA and IFN $\alpha$ for 24 hours. Whole cell protein was extracted and subjected to immunoblot with an anti- P2 IWAFI antibody, and, an anti-actin antibody as a loading control. B. MCF-7 cells were transfected with control scrambled or P2 IWAFI siRNA for 8 hours, followed by treatment with control, $0.02 \mu \mathrm{M}$ TSA and/or $500 \mathrm{IU} / \mathrm{ml}$ IFN $\alpha$ for 72 hours. The effect of the siRNAs on P2IWAFI gene and protein expression was analysed by semi-quantitative RT-PCR with the house-keeping gene $\beta$-2-microglobulin ( $\beta 2 \mathrm{M}$ ) as a loading control or by immunoblot, with actin as a loading control. C. Cell viability was examined by the Alamar blue assay, measured as optical density (OD) units of absorbance, and expressed as percentage of absorbance for drug-treated samples over control-treated samples (\% viable cells). ${ }^{* *} \mathrm{p}<0.0 \mathrm{I}$. 
A
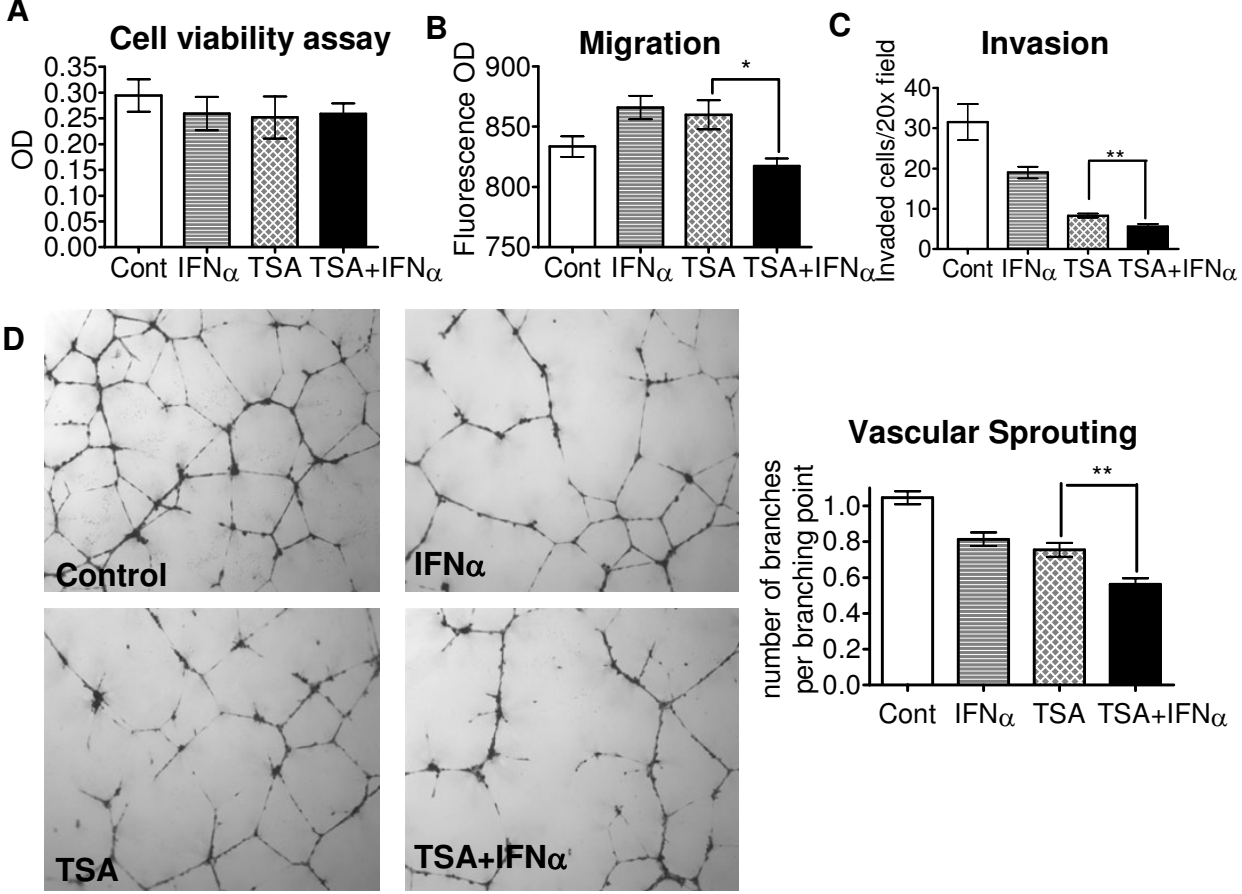

E

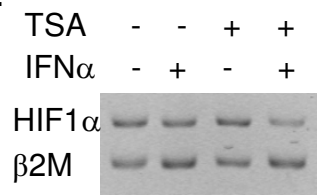

HIF1 $\alpha$
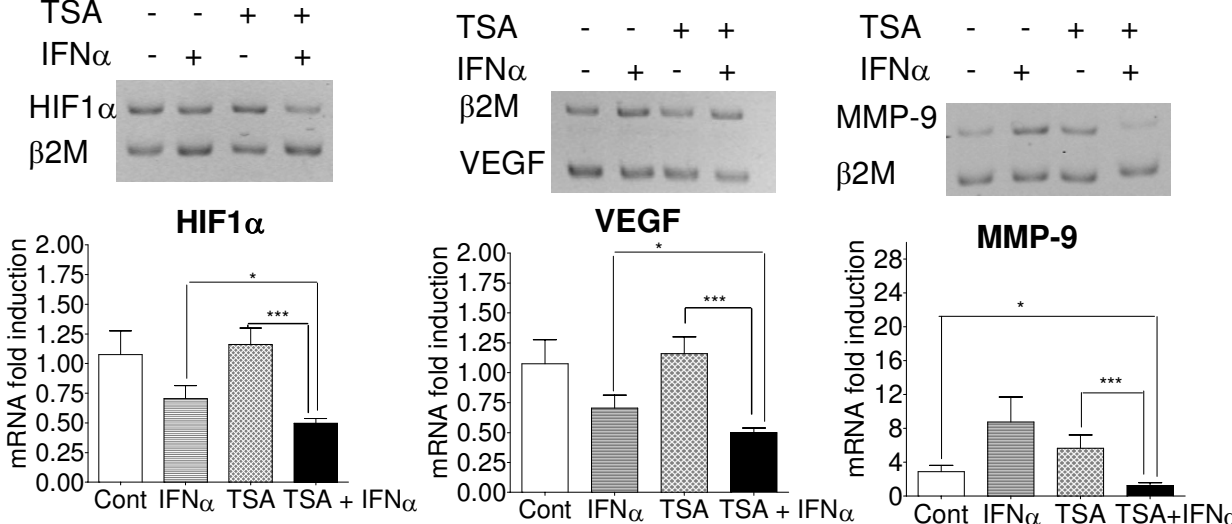

\section{Figure 5}

$\mathrm{HDACl}$ and IFN $\alpha$ co-operatively inhibit endothelial cell functions, and pro-angiogenic gene expression in cancer cells under hypoxic conditions in vitro. A. Human umbilical vein endothelial cells (HUVECs) were treated with control (Cont), $0.1 \mu M$ TSA and/or $500 \mathrm{IU} / \mathrm{ml} \mathrm{IFN} \alpha$ for 18 hours. Cell viability was evaluated with the Alamar blue assay. B. HUVECs were plated in BD Biosciences Fluroblok chambers and treated with control, $0.1 \mu \mathrm{M}$ TSA and/or $500 \mathrm{IU} / \mathrm{ml}$ IFN $\alpha$ for 22 hours. Cells were stained with Cell Tracker Green CMFDA, migrated through chamber filters toward the chemo-attractant VEGF, and then quantified and expressed as optical density (OD) absorbance units. C. HUVECs were plated into BD BioCoat growth factor-reduced matrigel invasion chambers and treated with control, $0.1 \mu \mathrm{M}$ TSA and/or $500 \mathrm{IU} / \mathrm{ml}$ IFN $\alpha$ for 18 hours. Cells which invaded through the Matrigel were fixed, stained with a Diff Quick staining kit, photographed and then quantified. D. HUVECs were plated onto growth factor-reduced Matrigel in 24 well plates and treated with control, $0.1 \mu M$ TSA and/or 500 IU/ml IFN $\alpha$ for I 8 hours. Vascular sprouting was quantified by counting the numbers of complete branches per branching point. E. Neuroblastoma $\mathrm{BE}(2)-\mathrm{C}$ cells were treated with control, $0.02 \mu \mathrm{M}$ TSA and/or $500 \mathrm{IU} / \mathrm{ml}$ IFN $\alpha$ for 72 hours under hypoxic (I\% $\left.\mathrm{O}_{2}\right)$ conditions. RNA was extracted and subjected to independent semi-competitive RT-PCR analyses using trans-intron PCR primers, together with primers for the house-keeping gene $\beta-2$ microglobulin $(\beta 2 M)$. Representative gels for each gene at the 72 hour time point were shown, and fold induction of a target gene by treatment was calculated by ascribing the ratio between the level of expression of a target gene and that of $\beta 2 \mathrm{M}$ as 1.0 for control treated samples. $* p<0.05, * * p<0.0 \mathrm{I}, * * * p<0.00 \mathrm{I}$. 
transgenic mice at four weeks of age, were treated with control, IFN $\alpha$, TSA, or TSA and IFN $\alpha$ for one week after abdominal tumors were first palpable. After mice were sacrificed, tumour volume was measured, and microvasculature assessed by immunohistochemical staining for platelet endothelial cell adhesion molecule 1 (PECAM-1) expression (Figure 6). When tumour volume was analysed, TSA alone suppressed tumour progression by $87 \%$, while IFN $\alpha$ alone reduced tumour volume by about $36 \%$, compared with control treated mice. The combination of TSA and IFN $\alpha$ reduced tumour volume by more than $92 \%$, although this was not statistically significant compared with TSA treatment alone. When tumour micro-vasculature was assessed by PECAM-1 staining, the use of TSA or IFN $\alpha$ alone, decreased micro-vasculature formation by $32 \%$ and $53 \%$, respectively. However, the combination of TSA and IFNa exerted co-operative anti-angiogenic effects, reducing micro-vasculature by almost $90 \%$ (Figure 6)

\section{Discussion}

HDACIs have shown great promise in clinical trials in cancer patients. However, a majority of patients have been insensitive to the treatment. In this study, we found that the combination of IFN $\alpha$ with the HDACI TSA induced co-operative cytotoxic effects in almost all cancer cell lines of diverse tissue types, and demonstrated little cytoxicity in normal non-malignant cells. The combination of IFNa with the HDACI SAHA, already in clinical use, also exerted co-operative anti-cancer effects, with little effect on normal cells. The combination of IFN $\alpha$ with another HDACI, VPA, was less effective than IFN $\alpha$ and TSA, but more effective than VPA and rapamycin. These results suggest that HDACI and IFN $\alpha$ combination therapy may be an effective anti-cancer strategy for future clinical trials.

Our data identified p21WAF1 expression as a key factor responsible for cancer cell resistance to the cytotoxic effects of combination HDACI and IFN $\alpha$ therapy. While IFN $\alpha$ can both induce or suppress p $21^{\mathrm{WAF} 1}$ gene transcription in different cells [19], it is the most common transcriptional target of HDACIs (reviewed in [2]). Previous literature suggested that up-regulation of p21 WAF1 by HDACIs may mediate HDACI-induced cell cycle arrest and growth inhibition [13]. However, recent publications have cast doubt on the role of p21WAF1 in the action of HDACIs, and, conversely demonstrated that inducible p21 ${ }^{\mathrm{WAF} 1}$ reduced HDACI-induced cell death [20-24]. Our
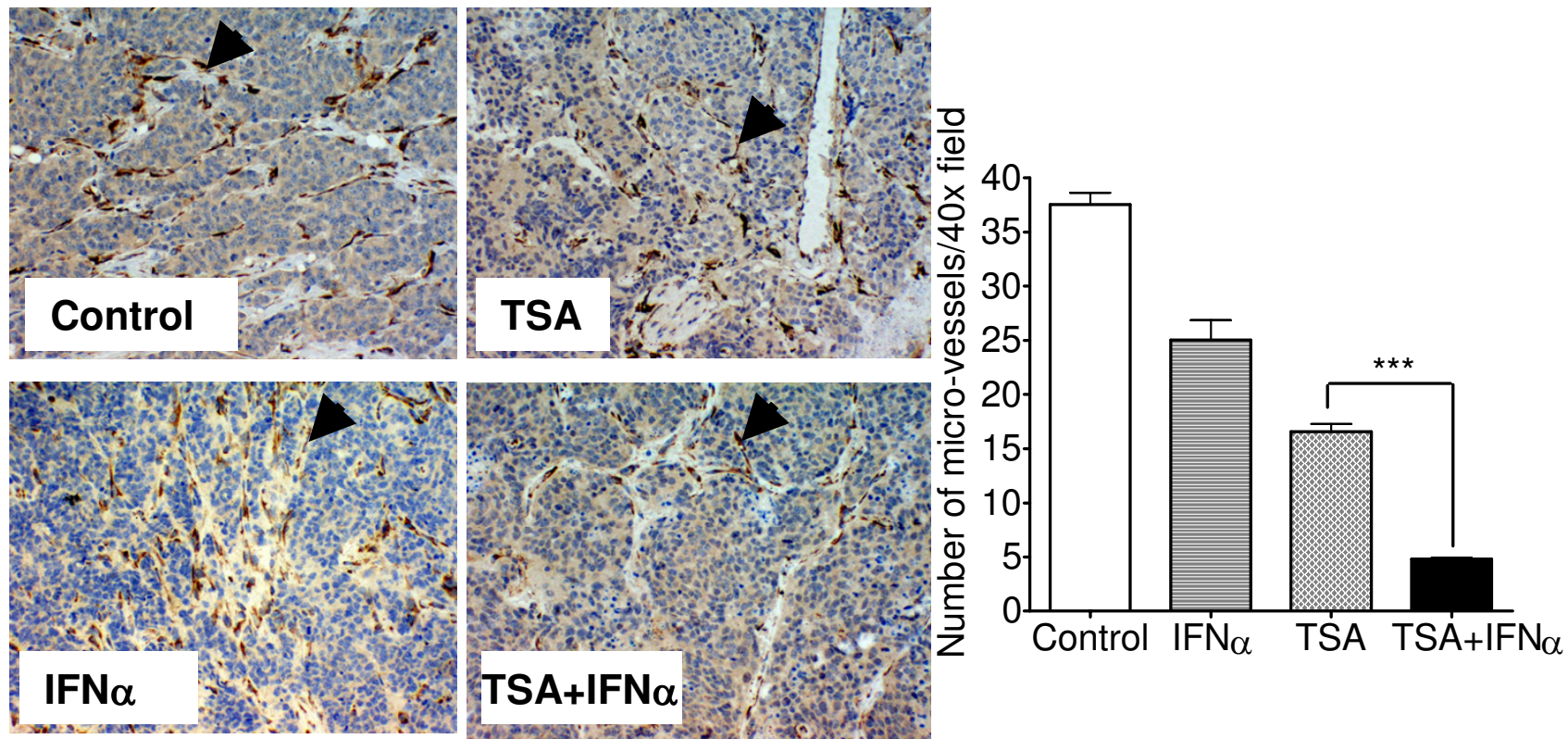

\section{Figure 6}

TSA and IFN $\alpha$ co-operatively suppress tumour-driven angiogenesis in neuroblastoma bearing transgenic MYCN mice. A. Photomicrographs of neuroblastoma tumour tissue sections from homozygous MYCN transgenic mice treated with either control, TSA, IFN $\alpha$, or TSA and IFN $\alpha$, which were subject to immunohistochemical studies using an anti-PECAM-I antibody. Arrows indicate PECAM-I positive microvessels (brown colored). B. Quantitation of the number of PECAM positive microvessels per $40 \times$ high power field in neuroblastoma tumour cross-sections. *** $p<0.00$ I. 
data suggests $\mathrm{p} 21^{\mathrm{WAF} 1}$ expression in some cancer cells acts as a resistance factor for the cytotoxic effects of TSA and IFN $\alpha$ combination therapy.

The individual effects of HDACIs and IFN $\alpha$ on angiogenesis predict a co-operative therapeutic role in blocking tumour angiogenesis. Expression of HDACs is often upregulated under angiogenic stimuli such as hypoxia in cancer cells, and HDACIs can suppress HIF1 $\alpha$ expression and its down-stream targets, including VEGF[25]. HDACIs have been recently demonstrated to inhibit endothelial cell migration, invasion, vascular sprouting in vitro, and vasculature formation in animal models of cancer $[14,16,26]$. IFN $\alpha$ can repress VEGF and MMP-9 gene expression, endothelial cell functions, and, inhibit tumour-driven angiogenesis in vivo $[9,27]$. In our endothelial cell migration experiments, we found in contrast, that either TSA or IFN $\alpha$ alone stimulated migration. We cannot fully explain the discrepancy between our data and previously published migration assays [14], however, this may be due to different characteristics of the migration chamber used. Importantly, the combination of HDACI and IFN $\alpha$ suppressed all endothelial cell functions, indicating a possible role for this drug combination as a therapy for cancer patients at the point of minimal residual disease.

\section{Conclusion}

In summary, we have found that the combination of HDACIs, TSA, SAHA and VPA, with IFN $\alpha$ have significant cytotoxic effects on a wide variety of cancer cells, with little toxicity to normal non-malignant cells. Inhibition of p21 WAF1 expression sensitizes p21 WAF1-expressing cancer cells to the combination therapy. Furthermore, HDACI and IFN $\alpha$ co-operatively suppress pro-angiogenic gene expression in cancer cells, multiple endothelial cell functions in vitro, and tumour-driven vasculature formation in vivo. Our results provide a basis for further in vivo studies and eventual clinical trials using the combination of HDACIs and IFN $\alpha$.

\section{Methods}

Cell culture and reagentsThe neuroblastoma cell line, $\mathrm{BE}(2)-\mathrm{C}$, was generously supplied by Dr J Biedler (Memorial Sloan-Kettering Cancer Center, NY, USA). Breast (MCF-7 and MDA-MB-468), lung (Calu-6 and H460), prostate (DU-145 and LNCaP), and, colon (HT-29 and Caco-2) cancer cells were purchased from American Type Culture Collection (Manassas, VA, USA). All cell lines were cultured in Dulbecco's modified Eagle's medium supplemented with $10 \%$ fetal calf serum, with the exception of $\mathrm{H} 460$ and LNCaP, which were cultured in Roswell Park Memorial Institute Medium, supplemented with $10 \%$ fetal calf serum. All cell lines were maintained in a humidified incubator at $37^{\circ} \mathrm{C}$ and $5 \% \mathrm{CO}_{2}$ in air.
TSA (Sigma, St. Luis, MO, USA) was dissolved in ethanol, and SAHA (BioVision, Mountain View, CA) in dimethylsulfoxide (Sigma). IFNa (Sigma) was diluted in serum free cell culture medium and aliquoted as a stock solution of $100000 \mathrm{units} / \mathrm{ml}$. For studies in animals, TSA was dissolved in dimethyl sulfoxide (Sigma) and further diluted with saline solution to give the final concentration of $30 \%$ dimethyl sulfoxide and $1 \mathrm{mg} / \mathrm{ml}$ TSA.

\section{Endothelial cell culture}

Human umbilical vein endothelial cells (HUVECs) were a gift from Dr K MacKenzie (Children's Cancer Institute Australia, Sydney, Australia). HUVECs were maintained in $0.1 \%$ gelatin coated tissue culture flasks or wells with medium 199 (Invitrogen, Carlsbad, CA, USA) supplemented with $20 \%$ fetal bovine serum, 5\% human serum (Sigma), $10 \mathrm{U} / \mathrm{ml}$ heparin (Pharmacia \& Upjohn, Peapack, NJ, USA), $5 \mathrm{ng} / \mathrm{ml}$ basic fibroblast growth factor (bFGF) (Sigma) and $20 \mathrm{ug} / \mathrm{ml}$ endothelial growth factor (Roche, Mannheim, Germany). Only passages 5 and 6 were used in the experiments. Hypoxic conditions were maintained in a chamber filled with $1 \%$ oxygen.

\section{Alamar blue cell viability assay}

After plating in 96 well plates, cells were allowed to attach for 24 hours, followed by treatment with various drugs for 72 hours. Before the end of treatment, cells were incubated with Alamar blue (Invitrogen) for 5 hours, and plates were then read on a micro-plate reader at 570/595 $\mathrm{nm}$. Relative cell viability was calculated according to the readings and expressed as optical density (OD) absorbance units.

\section{Immunoblot analysis}

Twenty four hours after treatment with control, TSA and/ or IFN $\alpha$, protein was extracted from whole cells, separated by electrophoresis, and transferred onto nitrocellulose membrane. Membranes were incubated with mouse antihuman p21 WAF1 antibodies (Santa Cruz Biotechnologies, Santa Cruz, CA, USA) (1:1000), followed by goat antimouse antibody (1:2000) conjugated with horseradish peroxidase. Chemiluminescent detection was performed using SuperSignal reagents (Pierce). Membranes were then re-probed with an anti- $\beta$-actin antibody (Pierce), as a loading control.

siRNA transfectionMCF7 cells were transfected with a validated scrambled siRNA or siRNA specifically targeting p21 WAF1 (SmartPool siRNA CDKN1A, Dharmacon Research, Lafayete, CO) with Lipofectamine 2000 transfection reagent (Invitrogen) according to the manufacturer's recommendation. Cells were lysed, and RNA or protein extracted 24 hours later for Reverse Transcriptionpolymerase Chain Reaction (RT-PCR) or immunoblot analysis of siRNA transfection efficacy. 


\section{Semi-quantitative competitive RT-PCR}

Semi-quantitative competitive RT-PCR was carried out as described previously [28] to analyse siRNA transfection efficiency in MCF-7 cells and the effect of TSA and/or IFN $\alpha$ treatment on angiogenic gene expression in $\mathrm{BE}(2)-\mathrm{C}$ cells. Specific primers used for PCR were as follows: 5'CAGCAGAGGAAGACCATGTG-3' and 5'-GGCGTTTGGA GTGGTAGAAA-3' for p21 WAF1; 5'-TTACAGCAGCCAGACGATCA-3' and 5'-ATTGCCCCAGCAGTCTACAT-3' for HIF1 $\alpha$; 5'-CCTTGCTGCTCTACCTCCAC-3' and 5'-ATGA TTCTGCCCTCCTCCTT-3' for vascular endothelial growth factor (VEGF); 5'-TTCCCTGGAGACCTGAGAAC-3' and 5'-AGGGACAGTTGCTTCTGGAG-3' for metalloproteinase-9 (MMP-9); 5'-ACCCCCACTGAAAAAGATGA-3' and 5'-ATCTTCAAACCTCCATGATG-3' for $\beta 2$-microglobulin $(\beta 2 \mathrm{M})$.

\section{Endothelial cell migration assay}

HUVEC migration towards the chemo-attractant, VEGF (Sigma), was tested using a BD Biosciences Fluroblok (Becton Dickinson) endothelial cell migration system according to the manufacture's guidelines. Cells were labeled with $1 \mu \mathrm{M}$ Cell Tracker Green CMFDA fluorescence solution (Invitrogen) for 30 minutes, and migrated through filters into 24 well plates. Thereafter the plate was read with a Fluroscence plate reader at $492 / 517 \mathrm{~nm}$. The relative cell number was calculated according to the readings and expressed as optical density (OD) absorbance units.

\section{Endothelial cell invasion assay}

HUVEC invasion through matrigel towards the chemoattractant, VEGF, was investigated using BD BioCoat, growth factor-reduced Matrigel, endothelial cell invasion chambers (Becton Dickinson), according to the manufacturer's guidelines. Endothelial cells which invaded through the matrigel to the other side of the inserts, were fixed and stained with Diff Quick staining kit (Baxter) and photographed. The number of cells per $20 \times$ objective field was counted under an inverted microscope.

\section{Vascular sprouting (capillary tubule formation) assay} The vascular sprouting assays were performed on 24 well plates coated with $250 \mu \mathrm{l}$ of polymerized, growth factorreduced Matrigel matrix (Becton Dickinson) per well. HUVECs were plated on Matrigel and treated with control, TSA and/or IFN $\alpha$ for 18 hours. Quantification of vascular sprouting was determined by counting the number of complete branches per branching point.

\section{Animal model studies}

As soon as tumors were confirmed by abdominal palpation, MYCN homozygous transgenic mice [18], were randomized to four groups ( $\mathrm{n}=5$ /group) and injected intraperitoneally daily for 7 days with control, TSA at 20 $\mathrm{mg} / \mathrm{kg}$ of body weight, mouse IFN $\alpha$ at $1 \times 10^{6} \mathrm{IU} / \mathrm{kg}$ body weight, or TSA and IFN $\alpha$. Mice were sacrificed at the end of the week of treatment. Tumors were then removed, formalin-fixed and paraffin-embedded. All studies involving animals were approved by the animal care and ethics committee of the University of New South Wales, Sydney, Australia.

\section{Immunohistochemical studies}

Mouse tissue sections were incubated with goat anti-platelet endothelial cell adhesion molecule 1 (PECAM-1) antibody (1:500) (Santa Cruz Biotechnology), followed by incubation with biotinylated rabbit, anti-goat antibody (1:500) and streptavidin-horseradish peroxidase. Endothelial cells were visualised with 3,3'-diaminobenzidine solution, and micro-vessels were quantified as described previously [29].

\section{Statistical analyses}

All data for statistical analyses were presented as mean \pm standard error. Differences were analyzed for significance using ANOVA among groups. A probability value of 0.05 or less was considered significant.

\section{Abbreviations}

bFGF: basic fibroblast growth factor; Cont: control; HDAC: histone deacetylase; HDACI: histone deacetylase inhibitor; HIF1 $\alpha$ : hypoxia-inducible factor $1 \alpha$; HUVEC: human umbilical vein endothelial cells; IFN $\alpha$ : $\alpha$-interferon; MMP-9: matrix metalloproteinase 9; OD: optical density; PECAM-1: platelet endothelial cell adhesion molecule 1; TSA: Trichostatin A; RAP: rapamycin; VEGF: vascular endothelial growth factor; VPA: valproate

\section{Competing interests}

The author(s) declare that they have no competing interests.

\section{Authors' contributions}

SK, TL, AT and TD performed experiments and analysed data. GMM, MH and MN designed experiments. TL and GMM analysed data and wrote the manuscript. All authors have read and approved the final version of the manuscript.

\section{Acknowledgements}

This work was supported by National Health and Medical Research Council, Cancer Institute New South Wales and Cancer Council New South Wales. Children's Cancer Institute Australia for Medical Research is affiliated with the University of New South Wales and Sydney Children's Hospital.

\section{References}

I. Johnstone RW: Histone-deacetylase inhibitors: novel drugs for the treatment of cancer. Nat Rev Drug Discov 2002, I (4):287-299. 
2. Liu T, Kuljaca S, Tee A, Marshall GM: Histone deacetylase inhibitors: multifunctional anticancer agents. Cancer Treat Rev 2006, 32(3): 157-165.

3. Marks P, Rifkind RA, Richon VM, Breslow R, Miller T, Kelly WK: Histone deacetylases and cancer: causes and therapies. Nat Rev Cancer 200I, I(3): 194-202.

4. Kelly WK, Marks PA: Drug insight: Histone deacetylase inhibitors--development of the new targeted anticancer agent suberoylanilide hydroxamic acid. Nat Clin Pract Oncol 2005, 2(3): $150-157$.

5. Folkman J, Kalluri R: Cancer without disease. Nature 2004, 427(6977): 787.

6. Bergers $G$, Benjamin LE: Tumorigenesis and the angiogenic switch. Nat Rev Cancer 2003, 3(6):40I-4I0.

7. von Marschall Z, Scholz A, Cramer T, Schafer G, Schirner M, Oberg K, Wiedenmann B, Hocker M, Rosewicz S: Effects of interferon alpha on vascular endothelial growth factor gene transcription and tumor angiogenesis. I Natl Cancer Inst 2003, 95(6):437-448.

8. Tosato G: Interferon-alpha is implicated in the transcriptional regulation of vascular endothelial growth factor. J Natl Cancer Inst 2003, 95(6):420-42I.

9. Brouty-Boye D, Zetter BR: Inhibition of cell motility by interferon. Science 1980, 208(4443):5I6-5I8.

10. Bjornsti MA, Houghton PJ: The TOR pathway: a target for cancer therapy. Nat Rev Cancer 2004, 4(5):335-348.

II. Cinatl J Jr., Kotchetkov R, Blaheta R, Driever PH, Vogel JU, Cinatl J: Induction of differentiation and suppression of malignant phenotype of human neuroblastoma $B E(2)-C$ cells by valproic acid: enhancement by combination with interferonalpha. Int / Oncol 2002, 20(I):97-106.

12. Michaelis M, Suhan T, Cinat I, Driever PH, Cinatl J Jr.: Valproic acid and interferon-alpha synergistically inhibit neuroblastoma cell growth in vitro and in vivo. Int J Oncol 2004, 25(6): $1795-1799$.

13. Richon VM, Sandhoff TW, Rifkind RA, Marks PA: Histone deacetylase inhibitor selectively induces p2 IWAFI expression and gene-associated histone acetylation. Proc Natl Acad Sci U S A 2000, 97(18): 10014-10019.

14. Kwon HJ, Kim MS, Kim MJ, Nakajima H, Kim KW: Histone deacetylase inhibitor FK228 inhibits tumor angiogenesis. Int J Cancer 2002, 97(3):290-296.

15. Kim MS, Kwon HJ, Lee YM, Baek JH, Jang JE, Lee SW, Moon EJ, Kim HS, Lee SK, Chung HY, Kim CW, Kim KW: Histone deacetylases induce angiogenesis by negative regulation of tumor suppressor genes. Nat Med 200I, 7(4):437-443.

16. Sasakawa Y, Naoe Y, Noto T, Inoue T, Sasakawa T, Matsuo M, Manda T, Mutoh S: Antitumor efficacy of FK228, a novel histone deacetylase inhibitor, depends on the effect on expression of angiogenesis factors. Biochem Pharmacol 2003, 66(6):897-906.

17. Slaton JW, Karashima T, Perrotte P, Inoue K, Kim S], Izawa J, Kedar D, McConkey DJ, Millikan R, Sweeney P, Yoshikawa C, Shuin T, Dinney CP: Treatment with low-dose interferon-alpha restores the balance between matrix metalloproteinase-9 and E-cadherin expression in human transitional cell carcinoma of the bladder. Clin Cancer Res 200I, 7(9):2840-2853.

18. Hansford LM, Thomas WD, Keating JM, Burkhart CA, Peaston AE, Norris MD, Haber M, Armati PJ, Weiss WA, Marshall GM: Mechanisms of embryonal tumor initiation: distinct roles for $\mathrm{MycN}$ expression and MYCN amplification. Proc Natl Acad Sci U S A 2004, I0I(34): I 2664-I2669.

19. Detjen KM, Murphy D, Welzel M, Farwig K, Wiedenmann B, Rosewicz S: Downregulation of p2 I (waf/cip-I) mediates apoptosis of human hepatocellular carcinoma cells in response to interferon-gamma. Exp Cell Res 2003, 282(2):78-89.

20. Burgess AJ, Pavey S, Warrener R, Hunter LJ, Piva TJ, Musgrove EA, Saunders N, Parsons PG, Gabrielli BG: Up-regulation of p2I(WAFI/CIPI) by histone deacetylase inhibitors reduces their cytotoxicity. Mol Pharmacol 200I, 60(4):828-837.

21. Nguyen DM, Schrump WD, Chen GA, Tsai W, Nguyen P, Trepel JB, Schrump DS: Abrogation of p2I expression by flavopiridol enhances depsipeptide-mediated apoptosis in malignant pleural mesothelioma cells. Clin Cancer Res 2004, 10(5): $1813-1825$.

22. Rosato RR, Almenara JA, Yu C, Grant S: Evidence of a functional role for P2 IWAFI/CIPI down-regulation in synergistic anti- leukemic interactions between the histone deacetylase inhibitor sodium butyrate and flavopiridol. Mol Pharmacol 2004, 65(3):57I-58I.

23. Qiu L, Burgess A, Fairlie DP, Leonard H, Parsons PG, Gabrielli BG: Histone deacetylase inhibitors trigger a $G 2$ checkpoint in normal cells that is defective in tumor cells. Mol Biol Cell 2000 I I (6):2069-2083.

24. Ungerstedt JS, Sowa Y, Xu WS, Shao Y, Dokmanovic M, Perez G, Ngo L, Holmgren A, Jiang X, Marks PA: Role of thioredoxin in the response of normal and transformed cells to histone deacetylase inhibitors. Proc Natl Acad Sci U S A 2005, 102(3):673-678.

25. Mayo MW, Denlinger CE, Broad RM, Yeung F, Reilly ET, Shi Y, Jones DR: Ineffectiveness of histone deacetylase inhibitors to induce apoptosis involves the transcriptional activation of NF-kappa B through the Akt pathway. J Biol Chem 2003, 278(2I): | $8980-18989$.

26. Qian DZ, Wang X, Kachhap SK, Kato Y, Wei Y, Zhang L, Atadja P, Pili R: The histone deacetylase inhibitor NVP-LAQ824 inhibits angiogenesis and has a greater antitumor effect in combination with the vascular endothelial growth factor receptor tyrosine kinase inhibitor PTK787/ZK222584. Cancer Res 2004, 64(18):6626-6634.

27. Ozawa S, Shinohara H, Kanayama HO, Bruns CJ, Bucana CD, Ellis LM, Davis DW, Fidler IJ: Suppression of angiogenesis and therapy of human colon cancer liver metastasis by systemic administration of interferon-alpha. Neoplasia 200I, 3(2): I54-I64.

28. Liu T, Bohlken A, Kuljaca S, Lee M, Nguyen T, Smith S, Cheung B, Norris MD, Haber M, Holloway AJ, Bowtell DD, Marshall GM: The retinoid anticancer signal: mechanisms of target gene regulation. Br J Cancer 2005, 93(3):310-318.

29. Qian DZ, Kato Y, Shabbeer S, Wei Y, Verheul HM, Salumbides B, Sanni T, Atadja P, Pili R: Targeting tumor angiogenesis with histone deacetylase inhibitors: the hydroxamic acid derivative LBH589. Clin Cancer Res 2006, I2(2):634-642.

Publish with BioMed Central and every scientist can read your work free of charge

"BioMed Central will be the most significant development for disseminating the results of biomedical research in our lifetime. "

Sir Paul Nurse, Cancer Research UK

Your research papers will be:

- available free of charge to the entire biomedical community

- peer reviewed and published immediately upon acceptance

- cited in PubMed and archived on PubMed Central

- yours - you keep the copyright
BioMedcentral 